\title{
The Effectiveness of the Flipped Classroom Model Using E-learning Media in Introduction to Information Technology Course
}

\author{
https://doi.org/10.3991/ijet.v14i21.10426 \\ Liranti Rahmelina $\left({ }^{\bowtie}\right)$, Fadil Firdian, Ilham Tri Maulana, Hesty Aisyah \\ STMIK Indonesia Padang, Padang, Indonesian \\ lirantirahmelina@stmikindonesia.ac.id \\ Jufriadif $\mathrm{Na}^{\prime}$ am \\ Universitas Putra Indonesia YPTK Padang, Kota Padang, Indonesia
}

\begin{abstract}
This study aimed to develop learning tools based on e-learning an introductory information technology course. e-learning, a web-based learning tool that uses classroom flipped learning models. The method used in this research was Analysis, Design, Development, Implementation, and Evaluation (ADDIE) with testing carried out on 22 students. The results of effectiveness through the calculation of the Gain score of 22 students 3 people who are of high value and 19 people are of medium value so that the overall average value of students has increased. The average increase in learning outcomes is 0.59 with a medium criteria. Then, it was concluded that e-learning using the flipped classroom learning model was very helpful in introducing Information Technology and as an e-learning guideline for other subjects.
\end{abstract}

Keywords-E-learning, Flipped Classroom, Learning Outcomes, Effectiveness, Analysis Design Development Implementation and Evaluation.

\section{Introduction}

The quality improvement of higher education is carried out in stages and continuously in various components of education, one of the educational components that is used as a reference by each education unit is the curriculum. Changes occur from year to year; currently the university curriculum, both those which have used the Indonesian National Qualifications Framework and those which have not, have formed learning designs in active learning and student centered learning [1]

The significance improvement is seen in technology users who can make educational changes in the teaching process or study in recent history [2]. The learning is a process that is implemented in the current development. Where, the current development of learning can be seen from technological developments. Students are very familiar with technology because most students already use technology in the form of laptops, computers, and smart phones. The development of Information Technology and Communication (ITC) or also called Information Technology (IT) that supports it 
daily necessities are very needed effective and efficient [3]. The technology used by students can present Student Centered Learning (SCL) approach. In the SCL learning approach, the instructor must carry out his/her role as a lecturer to students which is not as a lecturer, but also as a motivator, facilitator, and innovator [4]. This learning process determines the learning objectives will be achieved properly or not. Achievement of learning objectives can be seen from the learning program requires data about the implementation of learning and the level of achievement through the application of educational media applied to students.

Media Education is a change of educational activities form that introduces learning in practice and can socialize in both visual and text [5]. Studying by using media plays an important role in the learning process. The use of educational media can help lecturers in delivering lectures. The success of learning is determined by two main components, namely the method of teaching and learning media.

One of effective learning media is e-learning, the use of e-learning media is useful for learning that helps students obtain productivity as students or even if they complete tasks more efficiently [6]. The obtained productivity will improve the quality of students in understanding material learned by using e-learning. The application of effective e-learning media that is using a learning strategy, one of the learning strategies is flipped classroom.

A Flipped classroom is a pedagogical model or learning strategy in which traditional learning environments and activities are carried out changes, or at least reorganized [7]. This learning strategy utilizes technology as a supply of learning material that supports students in accessing material online. In its application, lecturers are given the freedom to plan. This results in the discretion of time used in class for learning. In flipped classroom, the material is first given in the form of e-learning which must be searched for web addresses, then read the material directed, e-learning also provides training and other supporting videos, all of which are done by students in their homes. On the other hand, in the learning session in the class, the process of group discussion and assignment is used. Lecturers act as directors and advisers if there is something that needs to be improved.

One of the subjects studied in the information system study program is an introduction to information technology which includes the latest technology in the field of information systems including computer networks, computer security and the introduction of information technology development methods. In Semester Lesson Plans introductory information technology courses, Learning Outcomes that must be prepared e-learning and mastered by students using a flipped classroom model, are figured in Table 1.

Table 1. Learning Outcomes in the Introduction to Information Technology Courses

\begin{tabular}{|c|c|l|}
\hline No & $\begin{array}{c}\text { Learning Out- } \\
\text { comes }\end{array}$ & \multicolumn{1}{c|}{ Description } \\
\hline 1 & $\begin{array}{c}\text { CPL - Study Pro- } \\
\text { gram }\end{array}$ & $\begin{array}{l}\text { Learning and using relevant terminology and basic concepts of current technolo- } \\
\text { gy. }\end{array}$ \\
\hline 2 & CP Course & $\begin{array}{l}\text { Students understand the historical and practical introduction to computers and } \\
\text { network terminology, applications, and concepts: } \\
\text { Students are expected to have experience with a variety of tools available to find }\end{array}$ \\
\hline
\end{tabular}




\begin{tabular}{|c|l|l|}
\hline & & $\begin{array}{l}\text { and access information on the Internet, to exchange information between com- } \\
\text { puters. } \\
\text { Students will explore applications (such as browsers and spreadsheets) and } \\
\text { different computing environments (such as Windows and UNIX). }\end{array}$ \\
\hline 3 & $\begin{array}{c}\text { Short description } \\
\text { of the course }\end{array}$ & $\begin{array}{l}\text { The course contains an introduction to technological information on the subject of } \\
\text { science and technology. Introduction to covering the history of development and } \\
\text { information technology, hardware, software, utilization, issues related to technolo- } \\
\text { gy and information. }\end{array}$ \\
\hline 4 & $\begin{array}{l}\text { Study Material / } \\
\text { Subject }\end{array}$ & $\begin{array}{l}\text { Hardware/ Software / Operating System / Networking: Introduction and Termi- } \\
\text { nology. Discussion of the different layers of technology in the present. Personal } \\
\text { computer, the definition and explanation of how digital technology saves and } \\
\text { manipulates the date, the key terms in the right context. Introduction to the Inter- } \\
\text { net and the World Wide Web. The history of the Internet began with the } \\
\text { ARPANET, moving to the beginning of the 1990s. Discussion of history and } \\
\text { challenges of several browsers, the need for a document format in general. The } \\
\text { discussion of the address and Internet protocol works, details relating to the } \\
\text { contents of the home network, and some security issues }\end{array}$ \\
\hline
\end{tabular}

Data Table 1 was the result of lecturers' deliberations including team teaching which teaches in introductory information technology courses. The data were used to make e-learning based media using classroom flipped learning models. The results of observations conducted by lecturers on introductory information technology courses at STMIK Indonesia Padang, found that learning outcomes were still low, below the standards set by the lecturers concerned, and the learning process still used conventional learning models (lectures) while this learning was one of the active courses. The proposed active learning can be applied to this situation without reviewing the material in each lecture in a row because it has been implemented into the learning media [8]. Higher education requires active learning; sophisticated technology creates active learning, for example, through the use of the Internet, the learning process results in a renewal in which lecture-centered education is transformed into studentcentered education.

Problem solving requires that all lecturers create an online knowledge with the help of electronic equipment that functions to train independent thinking then discuss the lesson in class by helping understanding [9]. The learning is generated using elearning contains material, learning videos, tasks that can be done anywhere and anytime so that learning becomes more effective.

The learning model integrated in e-learning is a classroom flipped learning model, this model has an irreplaceable advantage in modern teaching [9]. The modern learning model uses videos to present teaching discussions and create the latest ideas in improving students' skills.

Teaching flipped classroom models encourage students to watch videos, view material, and do assignments in teaching in their own time and form the concept of learning done at home, homework done at school [10].

\section{Research Methods}

E-learning based systems using flipped classroom model is a research program consisting of five phases that are used by educators who are adapted to the instruc- 
tional design model namely ADDIE Model [11]. ADDIE applies a system approach that includes five phases, namely Analysis, Design, Development, Implementation, and Evaluation. The ADDIE model obtains the development of e-learning, studying the example of Global University, an online institution that offered private tutoring to students and proposed a form of theoretical framework for e-learning design [12]. ADDIE is a guideline in building training tools and infrastructure programs that are effective, dynamic and support the performance of the training itself [13]. ADDIE models has stages in producing the desired output. The stages can be seen in Figure 1.

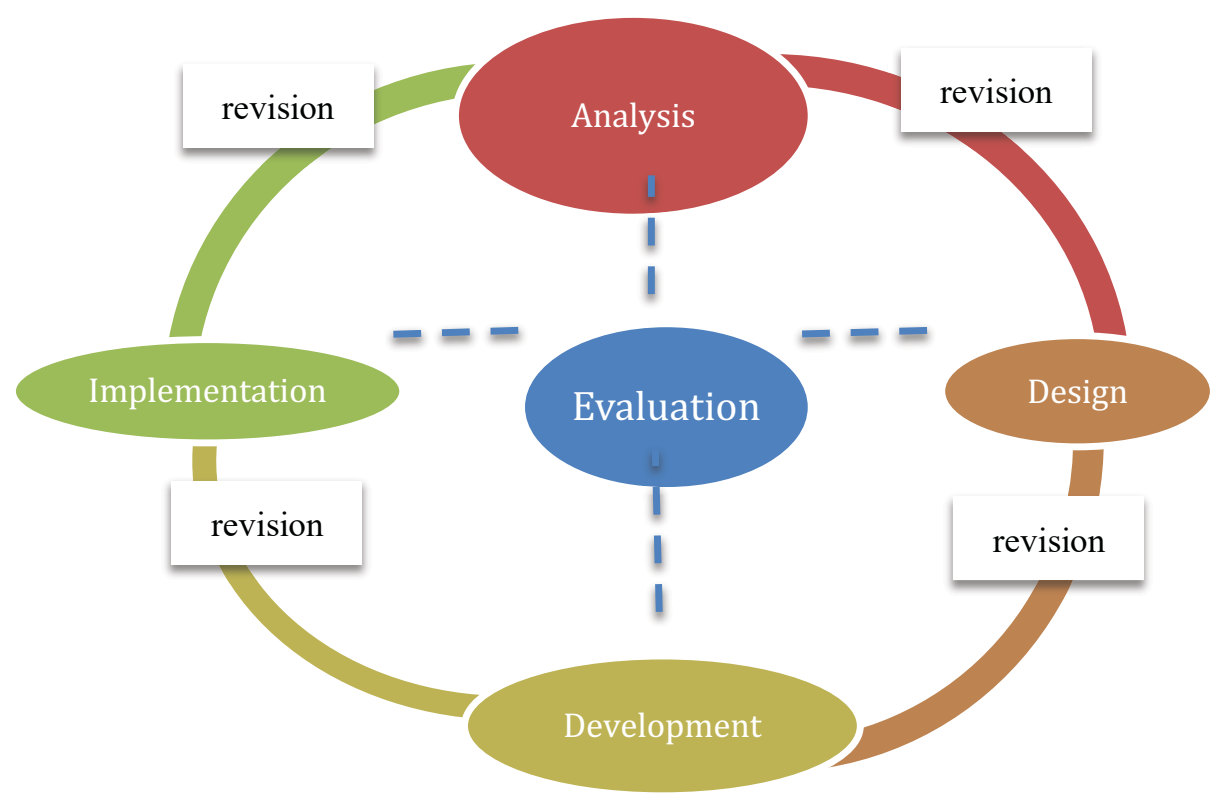

Fig. 1. ADDIE Model

The first stage was the Analysis stage. It was the stage to get the information needed to analyze the running system. Researchers constructed an effort by observing directly in complementing the needs of the object of research including the needs that support e-learning applications. Information about learning strategies that integrated with e-learning was flipped classroom where the system that runs was adjusted to the needs of the learning strategy. The Second Stage, namely Design. This stage identified learning such as e-learning, determining lecture material, assignments, learning videos, determining learning models using flipped classroom. Development Phase, this stage was the development stage of web-based e-learning applications. The implementation stage, this stage tested e-learning to students using the classroom flipped learning model. Evaluation stage, this stage measured the effectiveness of the flipped classroom learning model using e-learning media, effectiveness begins with measuring the Instrument Test questions included item validity test, item reliability test, 
difficulty index test and different power test, to find out the results of effectiveness seen from the results improvement of student learning.

\subsection{Test Instrument}

Validity

The formula used to calculate items validity is:

$$
\mathrm{r}_{\mathrm{pbi}}=\frac{\mathrm{M}_{\mathrm{p}}-\mathrm{M}_{\mathrm{t}}}{\mathrm{SD}_{\mathrm{t}}} \sqrt{\frac{\mathrm{p}}{\mathrm{q}}}
$$

- $\mathrm{r}_{\mathrm{pbi}}=$ Item validity coefficient

- $\mathrm{M}_{\mathrm{p}}=$ The average score calculated by the testee for items answered correctly

- $\mathrm{M}_{\mathrm{t}}=$ Average score of total score

- $\mathrm{SD}_{\mathrm{t}}=$ Standard deviation from total score

- $\mathrm{P}=$ Proportion of testee that answers correctly to items that are being tested for the validity of the item.

- $\mathrm{Q}=$ The proportion of the testee who answers incorrectly to the item that is being tested for the validity of the item

The item was valid if $r_{p b i}>r_{\text {tabel }}$

\section{Reliability}

The reliability of the test functioned to show whether a test was good enough to be used as a reliable data collection tool. To measure the reliability of the test in the study, the Richardson 21 formula (K-R.21) was used:

$$
r_{H}=\left(\frac{n}{n-1}\right)\left(1-\frac{M(n-M)}{n \cdot S_{t}^{2}}\right)
$$

- $\mathrm{r}_{\mathrm{H}} \quad=$ Reliability coefficient

- $\mathrm{n} \quad=$ the number of questions

- $\mathrm{M}=$ the average score test

- $\mathrm{S}_{\mathrm{t}}=$ Total variation in total score

The Classification of the Reliability Index can be classified as Table 2 .

Table 2. Classification of Question Reliability Indexes

\begin{tabular}{|c|c|c|}
\hline No & Distinction index & Classification \\
\hline 1 & $0.80 \leq \mathrm{r} \leq 1.00$ & Excellent \\
\hline 2 & $0.60 \leq \mathrm{r} \leq 0.80$ & Advanced \\
\hline 3 & $0.40 \leq \mathrm{r} \leq 0.60$ & Fair \\
\hline 4 & $0.20 \leq \mathrm{r}<0.40$ & Poor \\
\hline 5 & $0.00 \leq \mathrm{r}<0.20$ & Very Low \\
\hline
\end{tabular}


Each question its reliability level, so that it can be analyzed and classified the questions that will still be used in the tests that will be carried out after the application of the flipped classroom model.

\section{Problem Difficulty Index Test}

The test Index difficulty question is a number test that shows difficulty in the question. To determine the level of difficulty the equation was used :

$$
P=\frac{B}{J s}
$$

- $\mathrm{P} \quad=$ the level of difficulty

- $B=$ Number of students who answered the question correctly

- $\mathrm{J}_{\mathrm{S}}=$ the total number of students taking the test

The level of difficulty of the question could be classified as Table 3.

Table 3. Classification of the Difficulty Level of the Problem

\begin{tabular}{|c|c|c|}
\hline No & Difficulty Index & Classification \\
\hline 1 & $0.00 \leq \mathrm{P} \leq 0.30$ & Difficult \\
\hline 2 & $0.30 \leq \mathrm{P} \leq 0.70$ & Fair \\
\hline 3 & $\mathrm{P}>0.70$ & Easy \\
\hline
\end{tabular}

Index the difficulty of the question was conducted as a determination of whether the questions that have been made are categorized as difficult, fair, and easy.

\section{Discriminating Power}

The discriminating power functioned as indicators that distinguish between smart students (high ability) and less intelligent students (low ability).

The discriminating regulator formula is:

$$
\mathrm{D}=\frac{B_{A}}{J_{A}}-\frac{B_{B}}{J_{B}}=P_{A}-P_{B}
$$

- $\mathrm{D}=$ discriminating questions

- $\boldsymbol{J}_{\boldsymbol{A}}=$ the number of participants in the upper group

- $J_{B} \quad=$ the number of participants in the lower group

- $B_{A}=$ the number of upper group participants who answered correctly

- $B_{B}=$ the number of participants in the lower group who answered correctly

- $P_{A}=$ proportion of the upper group who answered correctly

- $P_{B}=$ proportion of lower groups who answered correctly

Discriminating power could be classified as table 4 .

Table 4. The classification of Discriminating Power

\begin{tabular}{|c|c|c|}
\hline No & Discriminating Power Index & Classification \\
\hline 1 & $0.70 \leq \mathrm{D}<1.00$ & Excellent \\
\hline 2 & $0.40 \leq \mathrm{D}<0.70$ & Good \\
\hline 3 & $0.20 \leq \mathrm{D}<0.40$ & Fair \\
\hline
\end{tabular}




\begin{tabular}{|c|c|c|}
\hline 4 & $0.00 \leq \mathrm{D}<0.20$ & Poor \\
\hline 5 & Negatif & Bad \\
\hline
\end{tabular}

Every question that was corrected needs a question that was still being used, so it was necessary to differentiate the questions that supported it.

\subsection{Analysis of learning outcomes}

Analysis of media effectiveness previously calculated the improvement in student learning outcomes that could be measured by comparing the value Midterm Test with Posttest. Improved learning outcomes were analyzed using the gain score formula according with the following formula [14]:

$$
<\mathrm{g}>=\frac{S_{f-S_{i}}}{100-S_{i}}
$$

- $\langle g\rangle=$ normalized gain score

- $S_{f}=$ posttests score

- $S_{i}=$ midterm Score

- $100=$ maximum score

The gain score gain level was categorized into three categories such as table 5:

Table 5. Gain Score Gain Rate

\begin{tabular}{|c|l|}
\hline Normalized Gain Score & \multicolumn{1}{c|}{ Interpretation } \\
\hline $\mathrm{g}>0.7$ & High \\
\hline $0.3<\mathrm{g} \leq 0.7$ & Medium \\
\hline $\mathrm{G} \leq 0.3$ & Low \\
\hline
\end{tabular}

The effectiveness of the media by using the classroom flipped learning model was determined by looking at the achievement of the completeness of students' learning outcomes using media implemented during the study. Furthermore, compared with before using information technology introductory lectures, in calculating the improvement in learning outcomes after comparing the Midterm test with the Posttest.

\section{$3 \quad$ Research Results and Discussion}

The results of the study were obtained using the ADDIE approach, Analysis, Design, Development, Implementation, and Evaluation.

\subsection{Conceptual Analysis from Research}

In this phase, the researchers described the conditions in the field. This stage analyzed the learning needs that were needed, so that they could be realized in a flexible 
learning atmosphere and learning facilities adapted to lectures [15]. At this stage the steps were as follows:

Results of university curriculum analysis: The higher education curriculum was based on KKNI, this curriculum reflected the development of innovation towards a demand, changes in the learning process became one of the achievements in this curriculum, conventional learning was transformed into technology-based learning.

\section{Result of participants analysis}

\section{- Students}

Students had facilities such as laptops, networks that support the realization of elearning media by using a flipped classroom model. The management of this function developed a learning environment that allowed all students to achieve their potential [16]. Students' facilities have not functioned well, so the student learning process was still conventional.

\section{- Lecturers}

Lecturers are instructors in the learning process that aim to achieve quality and improved learning. The improvement was in supporting student development and optimizing learning experience [17]. At present, lecturers has used conventional methods in the learning process. Learning that played an active role in the context of such discussions required inefficient meetings [17], this was the mastery and creativity of students in improving their abilities to be limited, and along with the meeting that also influenced the learning process.

\section{- Expected result}

Improving learning activities using e-learning media by implementing a flipped classroom model, students did the learning process in the form of viewing material, learning videos, carrying out the exercises at home. Whereas, in the class, they were carrying out discussions if there was incomprehension material learned at home. This activity would add insight into students in mastering the material. The optimal learning strategy would emerge, when looking back at the previous results [18]. These results were indicated from the learning outcomes of students who still have not mastered the material. The idea underlying the design of learning outcomes was to clarify the purpose of the learning process[19], therefore a change in learning strategies was held using e-learning media by implementing a flipped classroom model.

\subsection{Designing a learning system}

Designing a learning model: The learning model implemented in the flipped class model was an inverted learning model. This model was done at home using e-learning media. The introduction to information technology was a case study, this lecture required a global learning process. Learning and teaching are conducted globally aimed at influencing ways of learning that focus on developing online learning competencies [20]. Visual learning was the weakness of students' understanding of this lecture. E- 
learning can be done at home and anywhere, where e-learning provides materials, videos, training in learning that is in accordance with the teaching provided by previous lecturers. Classroom learning only discusses material that is poorly understood and gives conclusions.

Material Design: This design was begun from completing the material that would be input to e-learning media, after all teaching materials were input into e-learning media, users who were lecturers and students already had e-learning accounts. The next step was carried out in accordance with the lecture contract, At one meeting has two credit points with a time of 100 minutes of learning, consisting of 1 credit point (50 minutes) is conducted outside the classroom and 1 credit point (50 minutes) others implemented in classrooms tailored to the instruction between lecturers and students. This learning objective was that students were expected to be more active and master the lesson. Assessment weight could be seen from the results of training and activity in the learning process, in the e-learning section of the lecturer.

Learning Activity: In this activity, the lecturer implemented the learning towards conceptual learning goals in creating active learning [21]. This learning could be seen from the activities of students in accessing e-learning, starting from viewing material, learning videos. The context was used to facilitate distance learning and learning processes on campus [22]. In e-learning the lecturer informed the students to do the exercise with limited time, if the students wanted to ask, it was provided a chat to the lecturer if there was something wanted to be questioned. Learning activity at the campus was only a discussion, if there was still a lack of understanding about the material, the lecturer would be ready to become a student facilitator.

\subsection{Development of e-learning applications}

The development of e-learning used the Moodle application. This development used information technology to disseminate information and knowledge of education as a paradigm of modern education [23]. This application provided supporting tools in developing e-learning applications in accordance with the design.

\subsection{Implementation}

The implementation was the application of flipped classroom learning model using e-learning media. This implementation was described in accordance with Figure 1. 


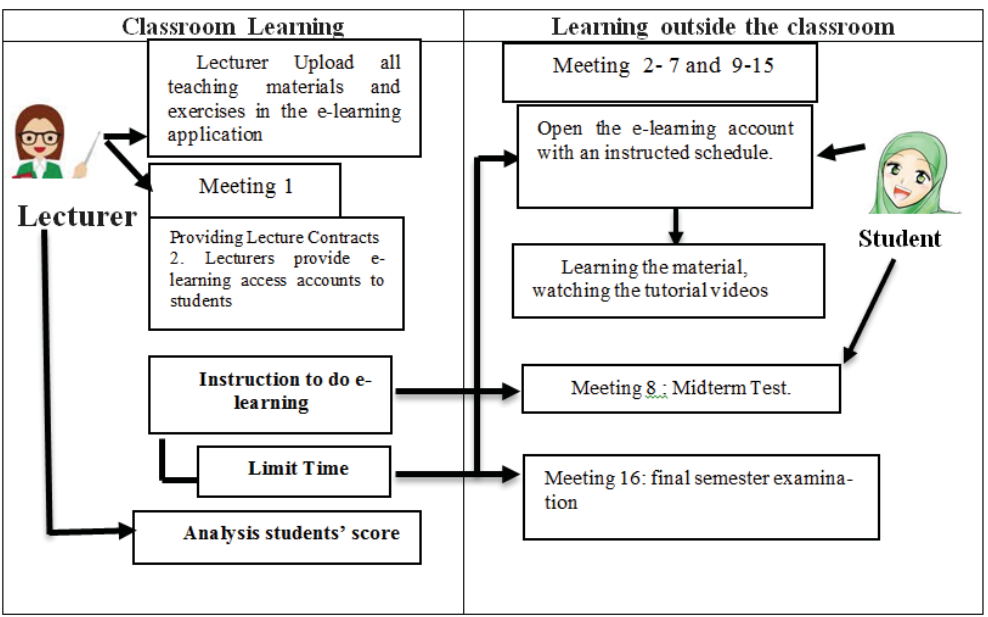

Fig. 2. Description of flipping classroom models using e-learning media.

Where:

\section{Lecturer}

- Input teaching materials and practice questions.

- Provided access to e-learning accounts for students.

- Gave instruction to use e-learning, in meeting 1 , discussed this learning process.

- Gave assignments to students, the time was limited.

- Analyzed student scores.

\section{Students}

- Having an e-learning lecture schedule.

- Opening login e-learning access.

- Conducting e-learning learning process

- Answering questions provided in e-learning.

\subsection{Evaluation}

\section{Stage of effectiveness}

Test Instrument questions: Before the test was given to the sample class, a trial was conducted to determine the validity, reliability, difficulty level of the question and distinguishing power.

- Test the validity of the item

Testing the validity of the test instruments was done by conducting a test on students of STMIK Indonesia Padang (outside of the sample) assuming that were carried out on introductory information technology courses, and on students with the same class. The results of the item validity test can be seen in Table 6 . 
Table 6. Test results for item validity

\begin{tabular}{|c|c|c|c|l|}
\hline No & Question & $\mathbf{r}_{\mathbf{p b i}}$ & $\mathbf{r}_{\text {table }}$ & \multicolumn{1}{|c|}{ Conclusion } \\
\hline 1 & Q1 & 0.585 & 0.361 & Valid \\
\hline 2 & Q2 & 0.498 & 0.361 & Valid \\
\hline 3 & Q3 & 0.530 & 0.361 & Valid \\
\hline 4 & Q4 & -0.542 & 0.361 & Invalid \\
\hline 5 & Q5 & 0.498 & 0.361 & Valid \\
\hline 6 & Q6 & 0.319 & 0.361 & Invalid \\
\hline 7 & Q7 & 0.512 & 0.361 & Valid \\
\hline 8 & Q8 & 0.388 & 0.361 & Valid \\
\hline 9 & Q9 & 0.160 & 0.361 & Invalid \\
\hline 10 & Q10 & 0.368 & 0.361 & Valid \\
\hline 11 & Q11 & 0.368 & 0.361 & Valid \\
\hline 12 & Q12 & 0.470 & 0.361 & Valid \\
\hline 13 & Q13 & 0.368 & 0.361 & Valid \\
\hline 14 & Q14 & 0.278 & 0.361 & Invalid \\
\hline 15 & Q15 & 0.416 & 0.361 & Valid \\
\hline 16 & Q16 & 0.149 & 0.361 & Invalid \\
\hline 17 & Q17 & 0.416 & 0.361 & Valid \\
\hline 18 & Q18 & 0.340 & 0.361 & Invalid \\
\hline 19 & Q19 & 0.491 & 0.361 & Valid \\
\hline 20 & Q20 & 0.452 & 0.361 & Valid \\
\hline 21 & Q21 & 0.534 & 0.361 & Valid \\
\hline 22 & Q22 & 0.642 & 0.361 & Valid \\
\hline 23 & Q23 & 0.170 & 0.361 & Invalid \\
\hline 24 & Q24 & 0.644 & 0.361 & Valid \\
\hline 25 & Q25 & 0.585 & 0.361 & Valid \\
\hline 26 & Q26 & -0.146 & 0.361 & Invalid \\
\hline 27 & Q27 & -0.039 & 0.361 & Invalid \\
\hline 28 & Q28 & -0.013 & 0.361 & Invalid \\
\hline 29 & Q29 & 0.607 & 0.361 & Valid \\
\hline 30 & Q30 & 0.443 & 0.361 & Valid \\
\hline & & & & \\
\hline 15 & & & & \\
\hline
\end{tabular}

From Table 6, there are 30 items of questions that are tested for validity. Of the 30 item questions there are 20 question items declared valid (rpbi> rtable), and 10 item questions declared invalid (rpbi <rtable). Valid item questions are questions that can be used to test student learning outcomes, while invalid items are questions that cannot be used to test student learning outcomes.

\section{- Test reliability test}

Test reliability was a measure of whether the test was reliable. The results of the calculation of reliability of the question were known that all the questions were reliable and more clearly could be seen as follows: The results of reliability using Microsoft Excel 2013 obtained a value of 0.60 . These results were compared with $r$ table. Tests were declared reliable if $\mathrm{r}$ is the result of calculation $>\mathrm{r}$ table. According to $\mathrm{r}$ table, for $\mathrm{N}=28$ and a significance level of $5 \%$, the value of $\mathrm{r}$ was 0.2787 . Then, we get $r$ count $>r$ table $=0.60>0.2787$. From the results of the analysis and based on the 
interpretation of the value of $r$, it could be indicated that the test had a high level of test reliability, which was 0.60 .

- The index of difficulty test

The index of difficulty of the questions was conducted to see whether the questions that have been made include the category of difficult, moderate or easy. Of all the questions that have been tested and then analyzed, the results indicated that 30 questions were classified as medium criteria.

- The test of discriminating power

Of all the questions that have been tested, a linear analysis was obtained that 2 questions were categorized as good, 18 were fair, and 10 were bad categories.

\subsection{Learning outcomes}

Based on the midterm test and posttest score, it was found that the sample class had an improvement in students' learning outcomes, so the analysis of the improvement in learning outcomes could be continued. Improving students learning outcomes could be measured through a comparison of the midterm test and posttest scored. Improved learning outcomes were analyzed using gain score according as in table 7.

Table 7. List of Midterm and Posttest Scores

\begin{tabular}{|c|c|c|c|c|c|c|}
\hline \multirow{2}{*}{ No } & \multirow{2}{*}{ Nama Siswa } & \multicolumn{2}{|c|}{ Nilai } & \multirow{2}{*}{ Smaks } & \multirow{2}{*}{ Gainscore } & \multirow{2}{*}{$<\mathbf{g}>$} \\
\hline & & $S i$ & $S f$ & & & \\
\hline 1 & Respondent 1 & 65 & 90 & 100 & 0.71 & High \\
\hline 2 & Respondent 2 & 60 & 85 & 100 & 0.63 & Medium \\
\hline 3 & Respondent 3 & 60 & 80 & 100 & 0.50 & Medium \\
\hline 4 & Respondent 4 & 50 & 75 & 100 & 0.50 & Medium \\
\hline 5 & Respondent 5 & 70 & 90 & 100 & 0.67 & Medium \\
\hline 6 & Respondent 6 & 60 & 75 & 100 & 0.38 & Medium \\
\hline 7 & Respondent 7 & 40 & 80 & 100 & 0.67 & Medium \\
\hline 8 & Respondent 8 & 65 & 80 & 100 & 0.43 & Medium \\
\hline 9 & Respondent 9 & 60 & 85 & 100 & 0.63 & Medium \\
\hline 10 & Respondent 10 & 65 & 95 & 100 & 0.86 & High \\
\hline 11 & Respondent 11 & 50 & 80 & 100 & 0.60 & Medium \\
\hline 12 & Respondent 12 & 55 & 80 & 100 & 0.56 & Medium \\
\hline 13 & Respondent 13 & 45 & 80 & 100 & 0.64 & Medium \\
\hline 14 & Respondent 14 & 70 & 95 & 100 & 0.83 & High \\
\hline 15 & Respondent 15 & 65 & 85 & 100 & 0.57 & Medium \\
\hline 16 & Respondent 16 & 60 & 85 & 100 & 0.63 & Medium \\
\hline 17 & Respondent 17 & 60 & 80 & 100 & 0.50 & Medium \\
\hline 18 & Respondent 18 & 55 & 70 & 100 & 0.33 & Medium \\
\hline 19 & Respondent 19 & 50 & 80 & 100 & 0.60 & Medium \\
\hline 20 & Respondent 20 & 65 & 85 & 100 & 0.57 & Medium \\
\hline 21 & Respondent 21 & 70 & 90 & 100 & 0.67 & Medium \\
\hline 22 & Respondent 22 & 65 & 85 & 100 & 0.57 & Medium \\
\hline \multicolumn{5}{|c|}{ Rata-rata } & 0.59 & Medium \\
\hline
\end{tabular}


Based on the calculation of the gain score, it was found that the overall average value of students had an improvement. The average improvement in learning outcomes was 0.59 with student gain score acquisition criteria. Therefore, it could be explained students learning outcomes in using the learning module declared effective.

\section{Conclusion}

This study provides an improvement in the process of introducing information technology by using a flipped classroom model that is conducted through e-learning media. This study can provide information to education providers, especially students, because the flipped classroom learning model using e-learning media can improve student learning outcomes because of its effectiveness. Lecturers can use this learning media, and always make updates so that their use is not only limited to information technology introductory material but can also be used for other learning. For other researchers, it is suggested to develop the similar things in other subjects.

\section{Acknowledgement}

This work was supported by Yayasan Amal Bakti Mukmin STMIK Indonesia Padang with contract number : 039/K.A/LPPM/STMIK-I/2018.

\section{References}

[1] F. Firdian and I. T. Maulana, "Development of Interactive Multimedia Learning Media in Software Application Courses," J. Pendidikan, Teor., Penelit. dan Pengemb., vol. Vol 3 No.6, pp. 822-828, 2018. https://doi.org/10.22216/jsi.v3i2.2350

[2] L. Farrell, "Challenging assumptions about IT skills in higher education," J. Learn. Dev. High. Educ., vol. 6, no. 6, 2013.

[3] L. Rahmelina, Y. Huda, P. Studi, P. Teknik, F. Teknik, and U. Negeri, "Mobile Learning Application Of Biological Science For Middle School Class X Students Based On Android (Case Study of SMA N 10 Padang)," Voteknika, vol. 2, no. 2, pp. 2-7, 2014.

[4] R. R. Antika, "Proses Pembelajaran Berbasis Student Centered Learning (Studi Deskriptif di Sekolah Menengah Pertama Islam Baitul 'Izzah, Nganjuk )," BioKultur, vol. 3, no. 1, pp. 251-263, 2014. https://doi.org/10.30957/konstruk.v10i1.460

[5] Marcus, A History of Media Education and Literacy, vol. 66. 2017.

[6] M. Aparicio, F. Bacao, and T. Oliveira, "Grit in the path to e-learning success," Comput. Human Behav., vol. 66, pp. 388-399, 2017. https://doi.org/10.1016/j.chb.2016.10.009

[7] Y. I. Chang and R. Chen, "Active learning with simultaneous subject and variable selections," Neurocomputing, no. xxxx, 2018.

[8] I. T. Awidi and M. Paynter, "The impact of a flipped classroom approach on student learning experience,” Comput. Educ., vol. 128, pp. 269-283, 2019. https://doi.org/10.1016 j.compedu.2018.09.013

[9] J. Li, X. Zhang, and Z. Hu, "The Design and Application of Flip Classroom Teaching Based on Computer Technology," iJET, vol. 13, no. 10, pp. 95-107, 2018. 
[10] S. Kanbul and F. Ozdamli, "Effects of the Gamification Supported Flipped Classroom Model on the Attitudes and Opinions Regarding Game-Coding Education," iJET, vol. 13, no. 1, pp. 109-123, 2018. https://doi.org/10.3991/ijet.v13i01.7634

[11] R. Sharifah and S. Faaizah, "The Development of Online Project Based Collaborative Learning using ADDIE Model,” Procedia - Soc. Behav. Sci., vol. 195, pp. 1803-1812, 2015. https://doi.org/10.1016/j.sbspro.2015.06.392

[12] S. Arabia, "Multimedia Based E-learning: Design and Integration of Multimedia Content in E-learning," iJET, vol. 9, no. 3, pp. 26-30, 2014.

[13] B. K. Sari, "Desain Pembelajaran Model Addie Dan Implementasinya Dengan Teknik Jigsaw," Desain Pembelajaran di Era ASEAN Econ. Community untuk Pendidik. Indones. Berkemajuan, pp. 87-102, 2017.

[14] 91367 USA Richard R. Hake, Dept. of Physics, Indiana University 24245 Hatteras Street, Woodland Hills, CA and In, ANALYZING CHANGE/GAIN SCORES, no. Division D. 1999.

[15] B. Santikarn and S. Wichadee, "Flipping the Classroom for English Language Learners : A Study of Learning Performance and Perceptions," iJET, vol. 13, no. 9, pp. 123-135, 2018. https://doi.org/10.3991/ijet.v13i09.7792

[16] K. P. Nightingale, V. Anderson, S. Onens, Q. Fazil, and H. Davies, "Developing the inclusive curriculum: Is supplementary lecture recording an effective approach in supporting students with Specific Learning Difficulties (SpLDs)?," Comput. Educ., vol. 130, pp. 13-25, 2019. https://doi.org/10.1016/i.compedu.2018.11.006

[17] A. Löfmark, G. Mårtensson, K. Johanne, U. Vae, and M. Engström, "LECTURERS , REFLECTION ON THE THREE-PART ASSESSMENT,” Nurse Educ. Pract., 2019.

[18] J. A. Bullinaria, "Evolution of learning strategies in changing environments," Cogn. Syst. Res., vol. 52, pp. 429-449, 2018.

[19] K. Kumpas-Lenk, E. Eisenschmidt, and A. Veispak, "Does the design of learning outcomes matter from students' perspective?," Stud. Educ. Eval., vol. 59, no. July, pp. 179-186, 2018. https://doi.org/10.1016/j.stueduc.2018.07.008

[20] J. Klein and G. Wikan, "Teacher education and international practice programmes: Reflections on transformative learning and global citizenship," Teach. Teach. Educ., vol. 79, pp. 93-100, 2019. https://doi.org/10.1016/j.tate.2018.12.003

[21] M. A. Simon, "Further elaboration of the Learning Through Activity research program," J. Math. Behav., vol. 52, no. June, pp. 224-229, 2018.

[22] J. Bicans and J. Grundspenkis, "Student Learning Style Extraction from On-Campus Learning Context Data," Procedia Comput. Sci., vol. 104, no. December 2016, pp. 272278, 2016. https://doi.org/10.1016/i.procs.2017.01.135

[23] W. A. Cidral, T. Oliveira, M. Di Felice, and M. Aparicio, "E-learning success determinants: Brazilian empirical study," Comput. Educ., 2018. https://doi.org/10.1016/j.c ompedu.2017.12.001

\section{$7 \quad$ Authors}

Liranti Rahmelina is a member of the IAENG (International Association of Engineers), Unit 1, 1/F,37-39 Hung to Road, Hong Kong. He works in the Information System Study Program at STMIK Indonesia Padang, Indonesia. . She focuses on research in the field of educational technology and decision support systems.

Ilham Tri Maulana is a member of the IAENG (International Association of Engineers), Unit 1, 1/F,37-39 Hung to Road, Hong Kong. He works in the Information 
System Study Program at STMIK Indonesia Padang, Indonesia. He focused on research in the field of educational technology.

Jufriadi Na'am is a member of the associate Professor in the Computer sciens at UPI YPTK. Faculty of Computer Science at Universitas Putra Indonesia YPTK Padang, Indonesia. He focused on research in Medical Image Processing, GIS (Geographic Information System), and education learning.

Fadil Firdian is a member of the IAENG (International Association of Engineers), Unit 1, 1/F,37-39 Hung to Road, Hong Kong. He works in the Information System Study Program at STMIK Indonesia Padang, Indonesia. . He focuses on research in the field of educational technology and interactive multimedia

Hesty Aisyah is a member of the IAENG (International Association of Engineers), Unit 1, 1/F,37-39 Hung to Road, Hong Kong. He works ain the Information System Study Program at STMIK Indonesia Padang, Indonesia. She focuses on research in education technology and management.

Article submitted 2019-03-07. Resubmitted 2019-07-26. Final acceptance 2019-07-26. Final version published as submitted by the authors 